\title{
Border Politics in the House: The Influence of the Congressional Border Caucus on Member Votes
}

\author{
W.R. Mack* \\ University of Southern Indiana, Evansville, IN 47715, USA

\begin{abstract}
This research probes the voting behavior of the Congressional Border Caucus in the U.S. House after the September 11, 2001 terrorist attacks. These attacks raised the consciousness of Congress, the media, and the public about the U.S-Mexico border and put the policy interests of the Border Caucus in the national spotlight. After the attacks, did caucus members adhere more closely to caucus positions that were important to border districts or more regularly vote against them? House votes on border and non-border amendments before and after the terrorist attacks are examined to determine if caucus members rallied to support the caucus majority on votes important to the border region after the attacks, or if factors such as party and ideology were more important influences on their votes. The findings reveal that Caucus members were indeed more supportive of border-related House amendments than non-Caucus members after the attacks. Yet, party and ideology still played a significant role in determining the votes of caucus and non-caucus members.
\end{abstract}

Keywords: Congressional caucus, U.S.-Mexico border, Amendment voting.

\section{INTRODUCTION}

Issues involving the borders that separate the United States from Mexico and Canada are getting more attention (mostly negative) from U.S. citizens, media, and government officials at all levels. Much of this intensified focus over the last decade can be attributed to the September 11, 2001 terrorist attacks on New York and Washington D.C. as many harbor fears that terrorists may infiltrate the relatively porous borders the U.S. shares with its southern and northern neighbors.

This is not to say that border problems have not drawn any attention in the past. Undocumented immigration, human trafficking, drug smuggling, and the flow of trade and travel across these common borders, for example, have been of great importance to all three countries for some time. Numerous channels of dialogue and negotiation have been established between the three North American countries and agreements have been signed to promote cross-border collaboration in the areas of transportation, health, trade, etc. (Congressional Research Service, Report \# RL33106, September 28, 2005).

\section{Congressional Response to Post-9/11 Border Anxiety}

With the outpouring of concern regarding American security in the wake of the $9 / 11$ attacks, it is reasonable to presume that Congress would concentrate more legislative attention on border affairs, addressing both short-term needs (i.e., shoring up border protection, cracking down on illegal immigration, etc.) and long-term ones (i.e., maintaining trade and free travel across the border, addressing the numerous

*Address correspondence to this author at the University of Southern Indiana, Evansville, IN 47715, USA; Tel: 812-465-1130;

E-mail:wrmack@usi.edu social needs of border communities, etc). ${ }^{1}$ Indeed, the U.S.Mexico border has been the hub of heightened deliberation and activity at all levels of government vis-à-vis our national boundaries. Laws passed by the Arizona and Georgia legislatures to have police check the immigration papers of suspected illegal immigrants are high-profile reflections of this anxiety.

Has this increased level of awareness of border affairs produced any notable changes in voting behavior in Congress on U.S.-Mexico border issues? One interesting place to look for such modifications in voting is informal "congressional member organizations," or congressional "caucuses" in the House of Representatives. These groups of like-minded legislators, unified in their interest in a specific topic, help to guide the legislative activity and voting behavior of their members. Of the dozens of congressional caucuses that are available for members to join, there is one that uniquely concentrates on matters related to the U.S.Mexico border - the Congressional Border Caucus. It is within the Congressional Border Caucus that I will look to find preliminary evidence of changes in House voting on border initiatives as a result of the $9 / 11$ terrorist attacks on American soil.

\section{THE INFLUENCE OF CONGRESSIONAL CAUCUSES ON LEGISLA TIVE BEHAVIOR IN THE HOUSE}

Caucuses were initially created to respond to changing demands in Congress (i.e., the growing number and complexity of issues facing the body, the rise in constituent pleas for responsiveness to those issues, etc.) that could not

\footnotetext{
One reaction from Congress to the new reality of foreign terrorist attacks in the U.S. was to change its institutional structure by reorganizing House and Senate committees and subcommittees with authority over homeland security matters. Largely, this involved shifting control over various security issues from several committees and subcommittees to one newly created umbrella committee in each house of Congress to focus the institution's attention and resources in one place (Davidson and Oleszek 2006).
} 
be easily reacted to through the formal congressional committee system (Ainsworth and Akins 1997; Hammond 1998). Legislatively, they serve multiple purposes. They gather information about topics of interest and make that material available to their members and others outside the caucus (Stevens, Mulhollan, and Rundquist 1981). This information may complement ideas advocated by standing committees or offset what committees have laid out for members (Ainsworth and Akins 1997). Caucuses sometimes identify potential solutions to problems as they provide leadership in setting the legislative agenda of Congress (Stevens, Mulhollan, and Rundquist 1981; Hammond 1998). To spread their ideas, caucus members testify at hearings, make floor statements, hold informal meetings and seminars, and lobby committees and subcommittees to produce favorable legislative outcomes for the members of the caucus and their constituencies (Stevens, Mulhollan, and Rundquist 1981). ${ }^{2}$ While developing strategies to pressure party leaders to adopt caucus-sponsored ideas (Stevens, Mulhollan and Rundquist 1981), caucuses also pursue favorable committee assignments for their members to push their policy agendas. ${ }^{3}$

While many House members would insist that policy concerns are their top priority in joining a caucus (Burgin 2003), they would also acknowledge that being a member of a caucus may impress one's constituency and make it look as if they are responsive to district policy preferences (Loomis 1981; Stevens, Mulhollan, and Rundquist 1981; Loomis and Schiller 2004). Since new members may not attain their preferred committee assignments, and thus, are at a disadvantage in participating in certain areas of policy (Hall 1996), caucuses become a place for members to branch out into areas unrelated to their assigned committees (Ainsworth and Akins 1997), and perhaps gain policy influence there (Loomis 1981; Dilger 1982). The benefits of simply belonging to a caucus, and establishing a formal commitment to an identifiable cause, are crystallized nicely in a quote by former representative (and former governor) of New Mexico Bill Richardson who said, "If someone writes me on an arts issue, I can write back and say, 'I'm a member of the Congressional Arts Caucus."' (Loomis 1988: 150)

When it comes to roll-call voting, Kingdon (1989) explains that links between members of Congress are valuable in facilitating decision-making on the floor of the House or Senate. A caucus is just such a linkage vehicle as it provides cues to assist its members on votes (Fiellin 1962), and often tries to organize caucus members and nonmembers into voting blocs that would support the objectives of the caucus (Stevens, Miller and Mann 1974; Preston 1978;

\footnotetext{
${ }^{2}$ The work of caucuses is not only concentrated within the halls of Congress as some caucuses work extensively with the executive branch. These contacts range from midlevel congressional liaison staffers all the way up to department secretaries and people on the White House staff who work in specific policy areas (Burgin 2003). Executive departments may consult with appropriate caucuses to assist their policy decisionmaking and seek the support of caucus members to gain momentum in selling White House initiatives to the rest of Congress. The heart of this study, the Congressional Border Caucus, has played such a role. In the mid-1980s, President Reagan's Task Force on Border Concerns consulted with members of the Congressional Border Caucus and asked them to testify at hearings held in the Southwest involving Reagan's immigration agenda (Hammond, Stevens and Mulholland 1985). Caucuses are also credited with successfully swaying various presidential administrations to strengthen textile and steel quotas and tariffs in the 1960s and 1970s (Stevens, Mulhollan and Rundquist 1981).

${ }^{3}$ Rohde (1989) details the effectiveness of the Conservative Democratic Forum (aka, the "Boll Weevils") in the mid-1980s in getting the House Democratic leadership to place CDF members in key committee positions.
}

Hammond, Mulhollan and Stevens 1983; Miller 1990; Vega 1993; Hammond 1998). ${ }^{4}$

\section{The Congressional Border Caucus}

There are a variety of topics taken up by caucuses that operate in the House. ${ }^{5}$ Our nation's borders with Mexico and Canada are one such cause that some House members have rallied around. In fact, there have been two distinct "border" caucuses in the House, the "Congressional Border Caucus" (highlighting the U.S.-Mexico border) and the "Congressional Northern Border Caucus" (emphasizing the U.S.-Canada border). This research will spotlight the work of the Congressional Border Caucus (CBC). ${ }^{6}$

According to the typology developed by Hammond (1991, 2001), congressional caucuses can be divided into six types: party, personal interest, national constituency, regional, state/district, and industry. The $\mathrm{CBC}$ falls into the "regional caucus" category. As defined by Hammond, regional caucuses work on areas of policy that are important to a particular geographic region. Likewise, its members come from states or districts that are adjacent to each other and view issues in a comparable manner. This definition certainly fits the CBC. Members of this informal group hail from the four states that abut the Mexican border California, Arizona, New Mexico and Texas. As explained by an aide to one caucus member, every House member from those four states who has a district that borders Mexico has become a member of the CBC (Rosso 2006). During the time period of this study, in the $106^{\text {th }}-108^{\text {th }}$ Congresses (1999-2004), there were ten members of the CBC - House members from two border districts in California, two in Arizona, one in New Mexico, and five in Texas. ${ }^{7}$ The party breakdown of CBC members for each Congress is as follows: in the 106th and 107th Congresses - six Democrats and four Republicans and in the 108th Congress - seven Democrats and three Republicans.

The evidence in the literature regarding the impact of a member's geographic region on their roll-call voting is mixed. Clausen (1973) finds that a member's home region plays a critical role in his/her policy positions, yet Hammond (2001) suggests that there is conflicting evidence that membership in a regional caucus influences a member's votes on regional matters of interest. The two regional caucuses she evaluates are the New England Caucus and the Northeast-Midwest Congressional Coalition. In her voting model, she notes that caucus membership in the NortheastMidwest Coalition had a statistically significant effect on votes in favor of the Coalition's positions on issues. The same could not be said for the effect of membership in the

\footnotetext{
${ }^{4}$ A caucus' role becomes even more important if, as Ainsworth and Akins (1997) contend, they provide unique information about the effect of legislation on individual districts that is hard to derive from committee or political party sources.

5 From the "Tax Equity Caucus" to the "Sudan Caucus" to the "Congressional Oral Health Caucus," the range of issues that caucuses have attempted to address is breathtaking.

${ }^{6}$ I look forward to doing future comparative studies of the similarities and differences that may exist between the membership, activities and voting patterns of the two border caucuses.

It should be explained that the ten members of the CBC were not the same ten members in each of the three Congresses examined here. Some senior members of the four state delegations retired and were replaced by new representatives during this period. Others saw redistricting after the 2000 census take their districts off the border with Mexico and put new districts on the border instead. Nevertheless, despite these Census-driven district boundary changes, the number of House districts sharing a border with Mexico did not change overall.
} 
New England Caucus on its members' votes in favor of caucus positions. Despite the divergent results in Hammond's research, she allows that relevant issues to a regional caucus "transcend party lines and are perceived as requiring cooperation or federal action to address." (Hammond 2001: 33)

In this research, a test of the influence of membership in the CBC on specific kinds of roll-call votes will be applied. An added twist to the model will be to see if the roll-call voting of $\mathrm{CBC}$ members, and a comparable group of nonCBC members, may have changed in light of the increased focus on the U.S.-Mexico border due to the 9/11 terrorist attacks. A pre-and post-test of voting on border and nonborder issues in the congresses before and after the attacks is used. The $106^{\text {th }}$ Congress was in session in the two years right before the attacks - 1999 and 2000 . The $107^{\text {th }}$ Congress was virtually split in half by the terrorist attacks, but a majority of House floor activity in 2001 was held before that fateful day. A small portion of the floor activity of 2001 (late-September through October), all of the floor action of 2002, and all of the activity of the $108^{\text {th }}$ Congress (2003-04) occurred after the terrorist attacks.

\section{HYPOTHESES}

In light of the uncertainty of Hammond's findings regarding the influence of regional caucus membership on roll-call voting, it is not clear whether to expect membership in the $\mathrm{CBC}$ to move members to consistently vote with the caucus' position on border amendments. Ostensibly, members of the House coalesce into informal congressional caucuses due to a shared legislative interest. Roll-call voting within the caucus can be facilitated through exchanges of information and "cues" that guide members on how to proceed with particular floor votes.

However, in asking $\mathrm{CBC}$ members to vote on the parochial border concerns of the caucus, it may run contrary to the post-9/11 pressure on individual members to serve the interests of the country at-large and more firmly monitor and restrict the free movement of people and goods across the U.S.-Mexico border. Which way should representatives turn when cross-pressured on such issues? Should they support a more closed border with Mexico that satisfies perceived national preferences? Or should they pursue policies that seek to allow freer flows of labor, travelers and goods between the two countries that bolster their local economies and international relationships?

The literature on congressional caucuses mostly affirms that caucuses supply a venue for individual representatives to work together toward common goals in specific policy areas (i.e., Loomis 1981). Yet, Burgin (2003) raises an interesting point about congressional caucuses that is germane to this debate. She suggests that caucuses that have a tight focus on just one or two issues (like the Diabetes Caucus in her research) will find it easier to build consensus between caucus members on the smaller set of goals they hope to achieve. The CBC does not fit Burgin's description. There are a wide-range of issues that are routinely addressed in "border" politics and many of these issues (handling illegal immigration, stopping drug trafficking, etc.) are riddled with controversy. Thus, it is expected in this analysis that $\mathrm{CBC}$ members would not automatically be sympathetic to $\mathrm{CBC}$ positions on border issues before the $9 / 11$ attacks, making it more difficult to rally caucus members to CBC positions.

What would be the reaction of $\mathrm{CBC}$ members after the 9/11 terrorist attacks? The U.S. government has put itself in a position where it is encouraging more commercial and cultural openness at the U.S.-Mexico border, while also attempting to clamp down on the illegal entry into the country of non-citizens who are often viewed as "undesirable" (Andreas 1998-99). The difficulty of simultaneously making the border more and less accessible to those who seek entry to the U.S. puts CBC members under great pressure to seek a border that is more secure while also endorsing one open enough in their home districts to allow human and commercial traffic flows to safely and efficiently continue. On the surface, the need for CBC members to keep the border as open as possible looks like a cause that would unify caucus members of both parties to work to attain this goal. With the dilemma above in mind, the following hypothesis is proposed:

$\mathrm{H}_{1}$ : Membership in the Congressional Border Caucus will have a statistically significant and positive influence on support for the caucus' positions on post-9/11 roll-call votes dealing with border issues, but not pre-9/11 votes dealing with similar issues.

Could working together affirmatively to pursue caucus goals on border concerns bleed over to member votes on non-border matters? Perhaps caucus membership has an influence on both types of votes, and therefore, is not unique to border subjects alone. Of course, the strong ties built through caucus membership and unanimity on border topics would have to trump other competing influences that often have primacy in a House member's voting calculus on any single issue, such as party or political ideology (Davidson, Oleszek and Lee 2008). Consequently, it is conjectured that on amendments not directed toward problems that impact the U.S.-Mexico border, CBC membership should not be a statistically significant factor on a member's vote. The following hypothesis reflects this supposition:

$\mathrm{H}_{2}$ : Membership in the Congressional Border Caucus will not have a statistically significant effect on a House member's vote in support of caucus positions on either pre-9/11 or post9/11 roll-call votes dealing with non-border issues.

\section{RESEARCH DESIGN - TESTING THE INFLUENCE OF THE CONGRESSIONAL BORDER CAUCUS}

\section{Unit of Analysis - Roll-Call Votes on House Amendments}

Choosing roll-call votes for quantitative analysis can be challenging. As part of her study of caucus activity in Congress, Hammond (2001) designed one voting model each for two separate congresses (the $97^{\text {th }}$ and $104^{\text {th }}$ Congresses) that included all roll-call votes of importance to seventeen different caucuses. These votes included final votes on bills, procedural votes on floor activity (adoption of House rules governing debate, for example), etc. The roll-call votes "of interest" to a caucus were determined through interviews with caucus members, party leaders and their staffs. Additional data was collected from surveys administered to caucus staff members and media reports on caucus activities. 
This research takes a different approach. It concentrates on roll-call votes on amendments offered on the floor of the House as the unit of analysis. Without direct knowledge of caucus positions on individual initiatives, selecting votes on border-related amendments is a suitable proxy for isolating those concerns that may be most important to the CBC. Furthermore, amendments are not omnibus in nature, which means they generally do not have more than one issue contained in them. In a multi-topic omnibus bill, it is difficult to isolate exactly which part(s) of a bill a member is reacting to as they cast their vote. A vote on an amendment is the most consistently direct vote on one idea you will find in the U.S. Congress.

"Border" related amendments were selected by reading through all floor amendments offered in the $106^{\text {th }}$ through $108^{\text {th }}$ Congresses. A modest number of these amendments make precise references to issues involving the U.S.-Mexico border or subjects that affect specific states sitting on the border. A few amendments make more general reference to "borders," but would certainly be relevant to House members whose districts adjoin Mexico. No amendments that appeared to affect only the U.S.-Canada border are included. Using these stipulations, thirty border amendments are identified for this analysis - three from the $106^{\text {th }}$ Congress, fourteen from the $107^{\text {th }}$ Congress, and thirteen from the $108^{\text {th }}$ Congress.

Moreover, this study will include, as a control, votes on non-border topics. ${ }^{8}$ Non-border amendments were randomly selected and oversampled at a rate of approximately fifty percent per Congress in comparison to border amendments to strengthen this test of caucus influence. Overall, six, twenty-one and eighteen randomly selected non-border amendments were added to the data from the $106^{\text {th }}, 107^{\text {th }}$ and $108^{\text {th }}$ Congresses, respectively. After the non-border amendments were chosen, the combined border and nonborder amendments were divided into two groups: those that received roll-call votes in the House before September 11, 2001 and those that received votes after that date.

\section{Selecting House Members for Roll-Call Analysis}

Naturally, the border and non-border amendment votes of the ten members of the CBC will be examined for each Congress. By comparison, their votes will be judged against the amendment votes of all non-CBC members from the House delegations of the four states that share a border with Mexico. Similar to the addition of non-border amendments into the analysis, incorporating the amendment votes of non$\mathrm{CBC}$ members from each state will provide a more stringent test of the influence of $\mathrm{CBC}$ membership on roll-call voting. The breakdown of $\mathrm{CBC}$ and non-CBC members by state, political party and Congress can be found in Table $\mathbf{1}$.

\section{The Voting Models}

A binary logit model will be used to examine the roll-call votes of $\mathrm{CBC}$ and non-CBC members on House floor amendments. The "n" for roll-call votes in the pre-9/11 period and post-9/11 period are 2438 and 4909, respectively. When analyzing the data, both pre- and post-9/11 data sets will be split according to the kinds of votes being cast -

\footnotetext{
${ }^{8}$ Votes that were not important to the caucuses investigated in Hammond's research were not included as a control in her voting model.
}

border and non-border votes. ${ }^{9}$ Examining the four data sets in this manner will permit a direct comparison of the influence of caucus membership and other independent variables on each member's votes for or against CBC positions on border and non-border amendments.

\section{Dependent Variable}

The dependent variable in each model is dichotomous. If a House member from one of the four border states voted in favor of the CBC's position on a floor amendment, they are assigned a " 1 " in the data for that vote. Those who vote against the CBC's position are assigned a " 0 " for that vote. Since the "official position" of the CBC on each amendment is not easily known, it will be measured by the direction that the caucus majority has voted on each amendment. Therefore, if six CBC members vote in favor of an amendment and four oppose it, the CBC's "official position" is in favor of the amendment, and each individual member's vote is assessed according to that standard. Without firm knowledge of the CBC's stated position on each amendment, this is an appropriate solution. It is an approach that has been used in the past by comparative politics researchers who study legislatures around the world, but have little or no data available to them on the official positions of political parties or coalitions that govern in various countries (i.e., Ames 2002).

\section{Measurement of Independent Variables}

The sixteen independent variables in this model mirror many of the ones commonly found in research on roll-call voting in informal caucuses (for example, Pinney and Serra 1999; Hammond 2001, etc.) as well as general voting research on American legislatures. Thirteen of the sixteen independent variables are dichotomous dummy variables. The remaining independent variables are measured as continuous or interval variables. Table $\mathbf{2}$ has complete explanations of how each independent variable in the voting model is measured.

\section{Independent Variable of Primary Interest \\ Membership in Congressional Border Caucus}

Of course, membership in the Congressional Border Caucus is the key independent variable to be tested here. Measured as a dummy variable, ten members in each Congress will receive a " 1 " in the data as participants in the Caucus. The remaining representatives in the model will be designated as " 0. ."

\section{Other Independent Variables}

\section{Political Party}

Generally, the literature on congressional voting behavior suggests that the party is a key influence on a representative's vote choices (Bond and Fleisher 1980; Bartels 1991; Erikson and Wright 2001, etc.) In spite of that, the informal caucus literature suggests that party concerns should fade into the background while caucus perspectives and positions become the focus of its members in order to

\footnotetext{
${ }^{9}$ Again, the pre-9/11 period in the study runs from January 1999 to September 11, 2001. This dataset consists of 871 border votes and 1567 non-border votes. The post911 period runs from September 12, 2001 through December 2004. This dataset consists of 1862 border votes and 3047 non-border votes.
} 
Table 1. House Members Included in the Amendment Voting Analysis

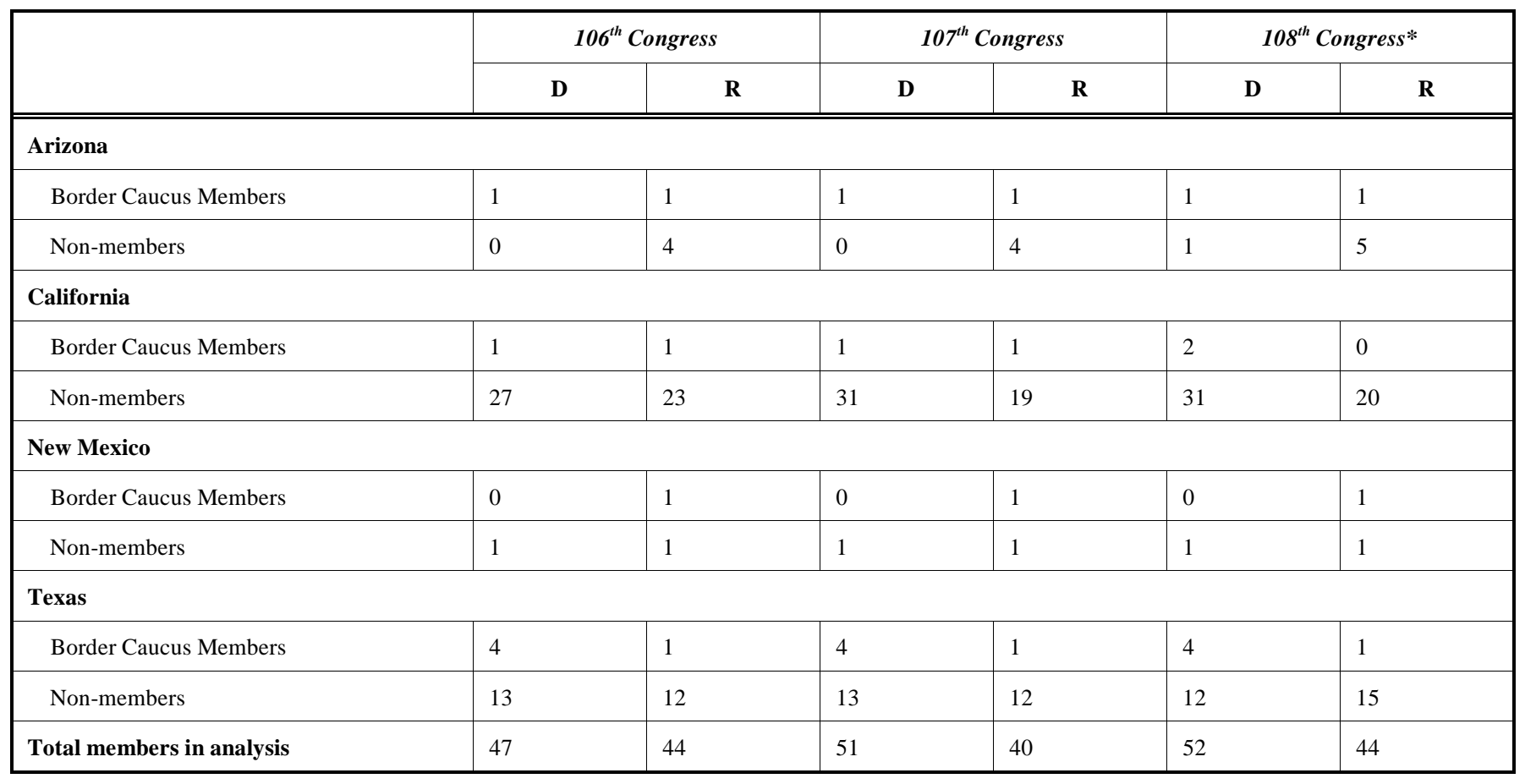

*The number of House members in Arizona, California and Texas all increased after reapportionment following the 2000 census.

Table 2. Operationalization of Independent Variables

\begin{tabular}{|c|c|}
\hline \multicolumn{2}{|l|}{ Dummy Variables } \\
\hline Caucus Membership & $1=$ Member of the Congressional Border Caucus \\
\hline Party & $1=$ Democrat \\
\hline Gender & $1=$ Male \\
\hline Seniority & $1=$ First-term member \\
\hline Party Leader & $\begin{array}{l}1=\text { Speaker of the House, Majority/Minority Leader, Majority/Minority Whip, Chief Deputy Whip, } \\
1=\text { Republican Conference Chairman, Democratic Caucus Chairman }\end{array}$ \\
\hline Prestige Committee & $1=$ Member of Appropriations, Rules, or Ways \& Means \\
\hline Border Subcommittee & $\begin{aligned} 1= & \text { Immigration and Claims (Judiciary) }-106^{\text {th }} \text { and } 107^{\text {th }} \\
& \text { Immigration, Border Security and Claims (Judiciary) }-108^{\text {th }} \\
& \text { Infrastructure and Border Security ( Select Committee on Homeland Security) }-108^{\text {th }}\end{aligned}$ \\
\hline State (3 dummy variables) & $1=$ Arizona, California, or Texas \\
\hline Vote topic 1 & $1=$ Defense/Security vote \\
\hline Vote topic 2 & $1=$ "Foreign" policy vote (includes trade and immigration) \\
\hline Electoral Marginality & $1=$ Received less than $60 \%$ of the vote in most recent election \\
\hline \multicolumn{2}{|l|}{ Interval Variable } \\
\hline Education & $\begin{array}{l}0=\text { Less than Bachelor's degree } \\
1=\text { Bachelor's degree } \\
2=\text { Graduate degree (Master's, Ph.D., J.D., etc.) }\end{array}$ \\
\hline \multicolumn{2}{|l|}{ Continuous Variables } \\
\hline Ideology & Americans for Democratic Action yearly vote support score \\
\hline Latinos in district & Percentage of Latinos in district based on 2000 census \\
\hline
\end{tabular}

Sources: Data collected from the Almanac of American Politics (2000, 2002, 2004, 2006) and personal correspondence with staff of Congressional Border Caucus members. 
protect the primary interests of caucus constituencies (Hammond 2001). ${ }^{10}$ When controlling for political party, Welch and Hibbing (1984) determine that representatives from southwestern states are generally more supportive of the preferences of Latinos [although Hero and Tolbert (1995) disagree]. Loomis (1981) and Burgin (2003) make similar assessments of the Northeast-Midwest Congressional Coalition and the Diabetes Caucus, respectively. Both conclude that partisanship is minimized by caucus members in the pursuit of issue objectives that will benefit the entire membership. Therefore, it is postulated here that a member's political party will not make a statistically significant impact on his/her votes on border amendments. Everyone in the CBC should pull together to serve their border constituencies without regard to their party affiliation, particularly after the 9/11 attacks.

\section{Gender}

Swers (2002) and Bratton (2002) both discover that gender has an influence on the types of issues legislators pay attention to in their work, while Bratton and Haynie (1999) insist that female representatives are more likely to substantively represent racial minorities (in the sponsorship of bills) than male lawmakers. In contrast, Knoll (2009) ascertains that women legislators are not more likely to vote in support of Latino interests than men. With such inconsistent conclusions, it is unclear whether gender would have an effect on support for CBC positions on border amendments, many of which address concerns that directly affect Latinos. Hence, it will be included in the analysis as a control variable.

\section{Education}

Education appears to play a role in how representatives view people of other races and ethnicities. Individuals with more education are generally more tolerant and positive toward immigrants and more accepting of less restrictive immigration policies (Espenshade and Calhoun 1993). Since issues involving immigrants often come up in "border" amendments proffered on the floor of the House, it is expected that members with higher levels of education will be more supportive of CBC positions on border amendments in these areas. There is an education variable in the model that separates $\mathrm{CBC}$ members and non-CBC members into three educational attainment groups - members with less than a bachelor's degree, with a bachelor's degree, and those with an advanced degree (master's, Ph.D., M.D., J.D., etc.)

\section{Seniority}

Those who are in their first terms in Congress are doing all they can to please their constituents, hoping it will help them in their first reelection campaign. Caucuses play a role here as they provide freshman representatives a means to establish some policy credibility in areas that may be outside of their standing committee expertise. Furthermore, caucuses help socialize first-term members into the profession and give them contact with senior members who provide information and advice on policy matters (Deckard 1972). Finally, caucuses provide a host of leadership positions from

\footnotetext{
${ }^{10}$ Although it is interesting to note that Democrats were more likely to belong to caucuses in the late 1990s than Republicans (Ainsworth and Akins 1997).
}

which a junior member can build up management credibility with colleagues (Hammond 1991). So, first-term members have much to gain by being conscientious in their work for a caucus and backing caucus policy positions, particularly on issues connected to the group's area of focus. ${ }^{11}$

\section{Party Leaders}

Swain (1992) observes that those who assume leadership positions in Congress (African-Americans, in her research) are subject to cross-pressures that force them to look out for broader interests, and not simply the interests of a specific constituency. Thus, it should be expected that party leaders will not be as aggressive in supporting the CBC position on border amendments as they might be without a leadership position. $^{12}$

\section{Members of House "Prestige" Committees}

Those who have seats on "prestige" committees (Appropriations, Rules, and Ways \& Means) labor under constraints that are similar to the ones party leaders must face. They must toil under the watchful eye of their colleagues and consider the effect of their work on the nation, their parties, and Congress itself. They do not have the luxury of exclusively looking out for the narrow affairs of any one group. They, too, should not be expected to back CBC positions on various border amendments.

\section{Border Subcommittees}

There are a few House subcommittees with jurisdiction in the area of border policy. With their familiarity with border issues, it is posited that anyone who serves on one of these subcommittees will be more motivated to protect border residents and their preferences and should be more supportive of CBC positions on border amendments.

\section{Amendment Subject Matter (Defense/Security Policy v. Foreign Policy v. Domestic Policy)}

Is it possible that amendment votes that CBC members cast will be affected by whether the amendments deal with foreign or defense policies rather than domestic ones? A recent opinion survey sheds some light on Latino policy preferences in eleven states that have larger Latino populations (Fraga et al., Latino National Survey, 2006). The four states from where CBC members hail (Arizona, California, Texas and New Mexico) are part of the survey. In the survey, "immigration" tops the list of issues most important to the Latino community. Consequently, it is clear that some key concerns in border communities are also significant in the Latino community at large.

If immigration issues are combined with others that affect border areas (freedom of movement across borders, trade, drug smuggling, etc.), a list of topics of consequence to border representatives can be compiled. It is votes cast by CBC members on House amendments that cover these items that are at the heart of this research. Amendments will be

\footnotetext{
${ }^{11}$ Despite the supposed benefits of freshmen legislators joining a caucus, Ainsworth and Akins (1997) discover that caucuses are not controlled by large numbers of junior members.

${ }^{12}$ Nonetheless, Stevens, Mulhollan and Rundquist (1981) and Burgin (2003) state that informal caucuses attempt to recruit party and committee leaders to join their ranks to take advantage of any potential legislative influence they might wield in reaching caucus goals. If nothing else, Burgin (2003) suggests, having leaders as caucus members brings a certain level of legitimacy to the organization.
} 
categorized in one of three groups - defense and security, "foreign" (immigration and trade), and domestic issues that affect border communities. ${ }^{13}$ Non-border amendments will also be included in the data set as a means to determine whether CBC members actually achieve more unity on all proposed amendments or only those that deal with border topics. ${ }^{14}$

The expectation is that given the choice between supporting local or national interests on restricting movement across the border, CBC members will unify behind positions that uphold local preferences. Subsequently, when $\mathrm{CBC}$ members are asked to support legislation increasing border security at the expense of freer travel and trade across the border, they will decline to do so. On the other hand, when non-border issues are voted on, CBC members may be influenced by other variables that often come into play when floor votes with less of a border emphasis are taken in the House.

\section{State Influence}

Clausen (1973) shows that a member's stances on policy are influenced by his/her home region. Welch and Hibbing (1984) agree and demonstrate that representatives from southwestern states are generally more supportive of Latino issues. To evaluate a potential individual state effect on support for border preferences, members of each state delegation in this analysis (Arizona, California, Texas and New Mexico) will be assigned a dummy variable signifying the state they represent.

\section{Electoral Marginality}

Electoral marginality has been reliably shown to shape the behavior of members of Congress in various ways (Mayhew 1974). For example, Rocca, Sanchez and Uscinski (2008) show that Latino members of Congress are more ideologically liberal in their voting as their electoral security grows. Here, it is postulated that being in a competitive electoral district (where a member received less than 60 percent of the two-party vote in their last election) will encourage $\mathrm{CBC}$ members to be more supportive of $\mathrm{CBC}$ positions on border amendments and exhibit their commitment to protecting the border interests of their constituents.

\section{House Member Ideology \\ Percentage of Latinos in a District}

In their study of Latino constituencies and representatives, Welch and Hibbing (1984) learn that the more Latinos there are in a House district, the more liberal a representative will vote, leading to more ideological substantive representation of Latinos in Congress. Hero and Tolbert (1995) and Knoll (2009), however, find that a larger Latino population in a district does not influence a representative to be more supportive of Latino issues. To test these inferences, this research model will include two

\footnotetext{
13 Examples of border amendments in the analysis: funding for a drug trafficking prevention program in "high traffic" communities (domestic), banning Mexican trucks from going beyond U.S. municipalities on the U.S.-Mexico border ("foreign"), allowing prescription drugs to be imported from outside the U.S. ("foreign"), and using the U.S. military to patrol our northern and southern borders (defense/security), etc.

${ }^{14}$ Examples of non-border amendments to be used in the analysis: tax relief (domestic), increased funding for the NEA (domestic), and prohibiting funding for space-based missile defense (defense/security), etc.
}

continuous variables that measure the ideology of both $\mathrm{CBC}$ and non-CBC members and the percentage of Latinos living in individual districts. The expectation is that a more liberal ideology [as measured by Americans for Democratic Action ratings (Pinney and Serra 1999)] and having more Latinos in a district (Hutchings 1998) will make it more probable that a representative will support CBC positions on border amendments than more conservative members or those who represent districts with smaller Latino communities.

\section{RESULTS}

\section{Pre-9/11 Border and Non-Border Amendment Models}

In the pre-9/11 border amendment model (see Table 3a), the only independent variables that have a statistically significant and positive influence on voting with the CBC position on border amendments is being a Democrat from one of the four border states and representing the state of Arizona. Conversely, serving on one of the three House "prestige" committees (Appropriations, Rules, Ways \& Means) or voting on a "foreign policy" topic (immigration or trade) had a negative effect on voting with the CBC position. This seems to back up the presumption that House members who are thought to be "leaders," such as those on "prestige" committees, may promote more expansive national interests, and not ones that are limited to more narrow local constituencies. It also looks to be the case that border state members who are not part of the CBC oppose the majority of their border brethren on "foreign policy" amendments. Perhaps the farther your district is from the border, the less those local concerns about keeping borders more open for free trade and immigration mean to you and a majority of your constituents.

In the pre-9/11 non-border amendment model, only those who are more liberal ideologically are more apt to vote for the CBC position on a non-border amendment. Conspicuously absent from the lists of statistically significant independent variables in both models is the CBC member variable. It appears that being a member of the $\mathrm{CBC}$ in the pre-9/11 period does not guarantee that the member will support the Caucus' position on either border or nonborder amendment votes.

\section{Post-9/11 Border and Non-Border Amendment Models}

The 9/11 terrorist attacks may have changed all that. Scrutiny of the post-9/11 border amendment model results reveal that $\mathrm{CBC}$ membership is statistically significant in a direction that suggests that members are more likely to support the Caucus' position concerning border matters than non-Caucus members. Also, Democratic border state members, members that have a higher percentage of Latino residents in their districts, and members that are more liberal in their ideology, are more prone to vote in favor of the $\mathrm{CBC}$ position on a border issue.

The similarity in results between the non-border amendments model and the border amendments model for the post-9/11 period is striking. CBC membership, being a Democrat, and possessing a more liberal ideology are statistically significant influences on a member's support for the $\mathrm{CBC}$ position on non-border measures, just as they are 
Table 3a. Binary Logistic Regression Model: Support for Congressional Border Caucus Positions on Border and Non-Border Amendment Votes

\begin{tabular}{|c|c|c|c|c|}
\hline Variable & $\begin{array}{c}\text { Pre-9/11 } \\
\text { Non-Border Amendment } \\
\text { Votes }\end{array}$ & $\begin{array}{c}\text { Pre-9/11 } \\
\text { Border-related } \\
\text { Amendment Votes }\end{array}$ & $\begin{array}{c}\text { Post-9/11 } \\
\text { Non-Border Amendment } \\
\text { Votes }\end{array}$ & $\begin{array}{c}\text { Post-9/11 } \\
\text { Border-related } \\
\text { Amendment Votes }\end{array}$ \\
\hline Caucus member & $\begin{array}{c}.217 \\
(.248)\end{array}$ & $\begin{array}{c}.378 \\
(.310)\end{array}$ & $\begin{array}{l}.453 * * \\
(.183)\end{array}$ & $\begin{array}{l}.543 * \\
(.249)\end{array}$ \\
\hline Party & $\begin{array}{c}.661 \\
(.358)\end{array}$ & $\begin{array}{c}1.548^{* *} \\
(.514)\end{array}$ & $\begin{array}{c}1.572 * * \\
(.289)\end{array}$ & $\begin{array}{l}.8188^{*} \\
(.370)\end{array}$ \\
\hline Gender & $\begin{array}{l}.180 \\
(.179)\end{array}$ & $\begin{array}{l}-.103 \\
(.211)\end{array}$ & $\begin{array}{l}-.220 \\
(.127)\end{array}$ & $\begin{array}{l}.000 \\
(.171)\end{array}$ \\
\hline Education & $\begin{array}{l}-.071 \\
(.100)\end{array}$ & $\begin{array}{l}.107 \\
(.129)\end{array}$ & $\begin{array}{l}.005 \\
(.078)\end{array}$ & $\begin{array}{c}.169 \\
(.099)\end{array}$ \\
\hline Party Leader & $\begin{array}{c}.393 \\
(.273)\end{array}$ & $\begin{array}{l}.265 \\
(.335)\end{array}$ & $\begin{array}{l}-.089 \\
(.201)\end{array}$ & $\begin{array}{l}.068 \\
(.270)\end{array}$ \\
\hline Seniority & $\begin{array}{c}.253 \\
(.200)\end{array}$ & $\begin{array}{l}.238 \\
(.253)\end{array}$ & $\begin{array}{l}.237 \\
(.145)\end{array}$ & $\begin{array}{l}-.075 \\
(.197)\end{array}$ \\
\hline Border Subcommittee & $\begin{array}{l}-.333 \\
(.264)\end{array}$ & $\begin{array}{l}-.415 \\
(.325)\end{array}$ & $\begin{array}{c}.002 \\
(.157)\end{array}$ & $\begin{array}{l}-.350 \\
(.199)\end{array}$ \\
\hline Prestige & $\begin{array}{l}-.169 \\
(.143)\end{array}$ & $\begin{array}{l}-.387 * \\
(.179)\end{array}$ & $\begin{array}{l}-.020 \\
(.107)\end{array}$ & $\begin{array}{l}-.026 \\
(.137)\end{array}$ \\
\hline Defense/Security Vote & $\begin{array}{c}-.218 \\
(1.176)\end{array}$ & $\begin{array}{l}-.209 \\
(.221)\end{array}$ & $\begin{array}{l}-.209 \\
(.110)\end{array}$ & $\begin{array}{l}-.003 \\
(.155)\end{array}$ \\
\hline "Foreign" policy vote & $\begin{array}{c}-.302 \\
(1.185)\end{array}$ & $\begin{array}{c}-.571^{* *} \\
(.178)\end{array}$ & $\begin{array}{l}.552^{* * *} \\
(.110)\end{array}$ & $\begin{array}{c}.094 \\
(.134)\end{array}$ \\
\hline Texas & $\begin{array}{c}.070 \\
(.361)\end{array}$ & $\begin{array}{c}.364 \\
(.448)\end{array}$ & $\begin{array}{l}.029 \\
(.270)\end{array}$ & $\begin{array}{l}-.327 \\
(349)\end{array}$ \\
\hline California & $\begin{array}{l}-.068 \\
(.354)\end{array}$ & $\begin{array}{l}-.040 \\
(.438)\end{array}$ & $\begin{array}{c}.037 \\
(.268)\end{array}$ & $\begin{array}{l}-.309 \\
(.348)\end{array}$ \\
\hline Arizona & $\begin{array}{l}-.089 \\
(.409)\end{array}$ & $\begin{array}{l}1.165^{*} \\
(.521)\end{array}$ & $\begin{array}{c}.003 \\
(.310)\end{array}$ & $\begin{array}{l}-.431 \\
(.397)\end{array}$ \\
\hline Electoral marginality & $\begin{array}{l}.055 \\
(.138)\end{array}$ & $\begin{array}{l}.061 \\
(.178)\end{array}$ & $\begin{array}{c}-.386^{* * *} \\
(.121)\end{array}$ & $\begin{array}{l}.007 \\
(.161)\end{array}$ \\
\hline Ideology & $\begin{array}{c}1.961^{* *} \\
(.457)\end{array}$ & $\begin{array}{l}-061 \\
(.635)\end{array}$ & $\begin{array}{c}1.093 * * \\
(.348)\end{array}$ & $\begin{array}{c}1.726^{* *} \\
(.454)\end{array}$ \\
\hline Latinos in district & $\begin{array}{l}.780 \\
(.437)\end{array}$ & $\begin{array}{c}.896 \\
(.511)\end{array}$ & $\begin{array}{l}.320 \\
(.299)\end{array}$ & $\begin{array}{c}1.169^{* *} \\
(.414)\end{array}$ \\
\hline Constant & $\begin{array}{c}-.801 \\
(1.261)\end{array}$ & $\begin{array}{l}-.626 \\
(.552)\end{array}$ & $\begin{array}{c}-1.320 * * \\
(.330)\end{array}$ & $\begin{array}{c}-1.099 * * \\
(.431)\end{array}$ \\
\hline Pseudo $\mathrm{R}^{2}$ & .239 & .169 & .294 & .275 \\
\hline $\mathrm{X}^{2}(d . f .=16)$ & 427.87 & 161.459 & 1060.031 & 598.711 \\
\hline-2 log likelihood & 1670.532 & 1023.726 & 3134.522 & 1886.872 \\
\hline $\mathrm{N}$ & 1567 & 871 & 3045 & 1860 \\
\hline
\end{tabular}

Notes: Standard errors for coefficients are in parentheses:

**Significant at the .01 level *Significant at the .05 level. 
for border amendments. There are just two differences between the models. First, House members from border states who represent marginal districts are less likely to vote with the CBC position on non-border amendments. Second, those members from districts with higher percentages of Latino residents are not more likely to vote with the CBC position than other members, as that variable is not statistically significant in the model.

Thus, Hypothesis \#1 is fully confirmed while Hypothesis \#2 is only partially confirmed. While it is true that CBC membership is a statistically significant influence on roll-call voting on CBC positions on border-related amendments (Hypothesis \#1), it is unexpectedly an important influence on non-border amendments in the post-9/11 period also (Hypothesis \#2 expects otherwise). It does seem odd that CBC members would not be more likely than non-CBC members to support the CBC position on border amendments in the pre-9/11 period of this study; however, it does give credibility to the idea that the tragedy of $9 / 11$ was a seminal event for caucus members. As the results of the post-9/11 models indicate, $\mathrm{CBC}$ members were more likely to coalesce behind their caucus' positions on border amendments as well as non-border ones in the post-9/11 interval, when they did not do so in the pre-9/11 period.

\section{One Additional Dilemma}

The results of the two post-9/11 models suggest that CBC members are more supportive of border and non-border floor amendments after the terrorist attacks of 2001 than before. That does leave one question that neither of the models can fully answer. Are CBC members of both political parties equally committed to $\mathrm{CBC}$ positions on border-related and non-border amendments, especially the border-related ones? Neither post-9/11 model differentiates by political party which CBC members have been most supportive of the caucus' floor amendment positions. As discussed earlier, regional caucuses tend to rise above party politics and give their members a common purpose to work toward. In this instance, closing the U.S.-Mexico border to terrorist activity and drug smuggling, while keeping it somewhat open for commerce, travel, and other key contacts between the two countries, should keep CBC members, regardless of party affiliation, unified in their attempts to resolve border concerns at the southern boundary of their districts. As structured, however, the post-9/11 models cannot determine if $\mathrm{CBC}$ members from one party are more sympathetic to $\mathrm{CBC}$ positions than their $\mathrm{CBC}$ colleagues from the opposition party.

To explore this matter further, the post-9/11 border and non-border amendment models are run again with a new interaction term - a dummy variable that combines the CBC membership and political party variables (see Table $3 \mathbf{b}$ ). ${ }^{15}$ In the non-border amendment model, the most notable finding is that the CBC membership variable is no longer statistically significant, and neither is the "CBC membership/political party" interaction variable, suggesting that $\mathrm{CBC}$ members from both parties are equally as likely to support the caucus majority on non-border amendments.

\footnotetext{
${ }^{15}$ Operationally, all CBC members who are Democrats are represented by a " 1 " in the data sets. All other House members in the data sets (Republican CBC members, Democrats and Republicans who are not CBC members) are assigned a "0."
}

The results are not the same for the post-9/11 border amendment model as an important change is observed. Here, the "CBC membership/political party" interaction term is statistically significant and in a direction that suggests that it is the Democratic caucus members, and not the Republicans, who are most likely to support post-9/11 border-related amendments. Surprisingly, party, by itself, is still a statistically significant variable suggesting that Democrats overall in the four border states are just as supportive of CBC positions on border amendments as they are non-border amendments. So, there appears to be a lot of unanimity between Democrats on the best course of action to take on House amendments of any kind. Furthermore, as in the original post-9/11 border amendment model, having a more liberal ideology, and representing a district that has a higher percentage of Latinos, gives a member a higher probability of supporting border-related amendments. The same is true for education - the higher the degree level a member has, the more likely they are to support border amendments in the post-9/11 period of this study.

\section{SUMMARY AND CONCLUSIONS}

Members of Congress are attracted to informal congressional caucuses for a whole host of reasons. They provide members an arena for working outside the formal congressional committee framework to achieve their personal and professional goals and permit them to concentrate on subjects that are of importance to their constituents. Sometimes unforeseen events put a policy area that is central to a particular caucus at the forefront of the consciousness of Congress, the media, and the public. Without a doubt, the terrorist attacks of September 11, 2001 drew the attention of Americans to its borders with Mexico and Canada.

Outside of Congress' formal committee system, caucuses have a role to play in the debate over border issues. Members of the Congressional Border Caucus, in particular, should have a vested interest in banding together to preserve the delicate line between strengthening the country's security and leaving the border open enough for enhanced trade, employment and travel opportunities.

According to the models here, $\mathrm{CBC}$ members have been more disposed to vote in favor of their caucus' positions on border and non-border amendments in the post-9/11 period than they were before the terrorist attacks of 2001. Yet, when the roll-call votes of greatest importance to the $\mathrm{CBC}$ (as posited, border-related amendments) are probed a bit further, it is revealed that Democratic CBC members are the ones toeing the $\mathrm{CBC}$ voting line. In reality, then, there has been no unanimity between Democratic and Republican CBC members on border amendments during the post-9/11 period. ${ }^{16}$

Why does this fissure exist between the two parties vis-àvis border amendments? Perhaps Republican members of the CBC seek to serve their representational goals in the caucus and are not using it to provide them with voting cues.

\footnotetext{
${ }^{16}$ Stevens, Mulhollan and Rundquist (1981) conclude that state delegations are often too diverse to act as a unit due to the differences between their districts. It is not a stretch to assume that similar disparities exist between the districts of regional caucuses like the $\mathrm{CBC}$, perhaps dampening the motivation of their representatives to work closely together on every issue.
} 
Table 3b. Binary Logistic Regression Model with Caucus Membership/Party Interaction Term: Support for Congressional Border Caucus Positions on Border and Non-Border Amendment Votes

\begin{tabular}{|c|c|c|}
\hline Variable & $\begin{array}{c}\text { Post-9/11 } \\
\text { Non-Border Amendment Votes }\end{array}$ & $\begin{array}{c}\text { Post-9/11 } \\
\text { Border-related Amendment Votes }\end{array}$ \\
\hline Caucus member & $\begin{array}{l}.334 \\
(.254)\end{array}$ & $\begin{array}{l}.141 \\
(.304)\end{array}$ \\
\hline Caucus member + party & $\begin{array}{l}.231 \\
(.338)\end{array}$ & $\begin{array}{l}1.283^{*} \\
(.562)\end{array}$ \\
\hline Gender & $\begin{array}{l}-.227 \\
(.127)\end{array}$ & $\begin{array}{l}-.022 \\
(.170)\end{array}$ \\
\hline Education & $\begin{array}{l}.012 \\
(.078)\end{array}$ & $\begin{array}{l}.200^{*} \\
(.101)\end{array}$ \\
\hline Border Subcommittee & $\begin{array}{l}.005 \\
(.156)\end{array}$ & $\begin{array}{l}-.334 \\
(.197)\end{array}$ \\
\hline Prestige & $\begin{array}{l}-.004 \\
(.109)\end{array}$ & $\begin{array}{l}.041 \\
(.139)\end{array}$ \\
\hline Defense/Security Vote & $\begin{array}{l}.120 \\
(.110)\end{array}$ & $\begin{array}{l}.004 \\
(.155)\end{array}$ \\
\hline "Foreign" policy vote & $\begin{array}{l}.552 * * \\
(.110)\end{array}$ & $\begin{array}{c}.093 \\
(.134)\end{array}$ \\
\hline Electoral marginality & $\begin{array}{c}-.373 * * \\
(.122)\end{array}$ & $\begin{array}{l}.061 \\
(.163)\end{array}$ \\
\hline Ideology & $\begin{array}{c}1.092^{* *} \\
(. .348)\end{array}$ & $\begin{array}{c}1.737 * * \\
(.455)\end{array}$ \\
\hline Latinos in district & $\begin{array}{l}.299 \\
(300)\end{array}$ & $\begin{array}{c}1.066^{* * *} \\
(414)\end{array}$ \\
\hline Constant & $\begin{array}{c}-1.281 * * \\
(.335)\end{array}$ & $\begin{array}{c}-.972 \\
(. .436)\end{array}$ \\
\hline Pseudo $\mathrm{R}^{2}$ & .294 & .278 \\
\hline $\mathrm{X}^{2}(d . f .=16)$ & 1060.504 & 599.261 \\
\hline-2 log likelihood & 3134.049 & 1880.755 \\
\hline $\mathrm{N}$ & 3045 & 1860 \\
\hline
\end{tabular}

Notes: Standard errors for coefficients are in parentheses:

**Significant at the .01 level *Significant at the .05 level 
Instead, Republicans may rely on their party, lobbying groups, or the perceived interests of specific segments of their constituency as the principal cues for their roll-call decision-making on these amendments.

Remember, too, that the data suggest that a more liberal ideology can play a major role in a CBC member's decision to support the caucus' position on virtually any issue. Since the Democratic portion of the CBC appears to be more liberal (as evidenced by their ADA scores), that, in combination with the influence of political party, may make them predisposed to voting with CBC positions.

Burgin's (2003) assertion about the policy orientations of congressional caucuses seems to be confirmed here, also. Unlike caucuses that concentrate on one issue, the party split in the CBC over support of caucus positions may reflect more general conflict on the expansive group of issues that are addressed in "border" politics. With contentious disputes about how to resolve challenges in immigration, trade, etc., it is likely tougher to get caucus members to champion $\mathrm{CBC}$ positions in light of the $9 / 11$ attacks. The Democrats and Republicans in the CBC are not in lockstep on how to address the multitude of problems that confound the U.S.Mexico border. The cross-pressures of party and ideology may simply be too difficult for the CBC to overcome.

The House Congressional Border Caucus is one small part of the extensive caucus web that tries to influence policymaking in Congress and the executive branch. Future studies of the $\mathrm{CBC}$, where it is compared to other caucuses, should tease out details of the level of influence and solidarity that $\mathrm{CBC}$ members have in helping to secure our borders, while trying to serve separate constituencies that favor a more open border.

\section{CONFLICT OF INTEREST}

None declared.

\section{ACKNOWLEDGEMENTS}

I would like to thank the Lilly Endowment, Inc. for summer funding to work on this research. An earlier version of this paper was presented at the Northeastern Political Science Association Conference, Boston, MA, November 2010.

\section{REFERENCES}

Ainsworth, S., \& Akins, F. (1997). The information role of caucuses in the U.S. congress. American Politics Quarterly, 25(4), 407-30.

Ames, B. (2002). Party discipline in the Chamber of Deputies. In S. Morgenstern \& G. Nacif (Eds.), Legislative politics in latin America (pp. 185-221). Cambridge: Cambridge University Press.

Andreas, P. (1998-1999). The escalation of U.S. immigration control in the post-NAFTA era. Political Science Quarterly, 113(4), 591-615.

Barone, M., \& Ujifusa, G. (2000, 2002, 2004, 2006). The almanac of American politics. Washington, DC: National Journal.

Bartels, L. M. (1991). Constituency opinion and congressional policy making: the reagan defense buildup. American Political Science Review $85,457-74$.

Bond, J., \& Fleisher, R. (1980). The limits of presidential popularity as a source of influence in the U.S. house. Legislative Studies Quarterly 5, 69-78.

Bratton, K.A. (2002). The effect of legislative diversity on agenda setting: evidence from six state legislatures. American Politics Research, 30(2), $115-42$.
Bratton, K.A., \& Haynie, K.L. (1999). Agenda setting and legislative success in state legislatures: the effects of gender and race. Journal of Politics, 61(3), 658-79.

Burgin, E. (2003). Congress, health care, and congressional caucuses: an examination of the diabetes caucus. Journal of Health Politics, Policy and Law, 28(5), 789-820.

Clausen, A. (1973). How congressmen decide: a policy focus. New York: St. Martin's Press.

Congressional Research Service (2005). Border security and the Southwest Border: background, legislation, and issues. Report \# RL33106. Washington, DC: The Library of Congress.

Davidson, R., \& Oleszek, W. (2006). Congress and its members, $10^{\text {th }}$ ed. Washington DC: CQ Press.

Davidson, R., Oleszek, W., \& Lee, F. (2008). Congress and its members, $11^{\text {th }}$ ed. Washington DC: CQ press.

Deckard, B. (1972). State party delegations in the U.S. house. Journal of Politics 34, 199-222.

Dilger, R.J. (1982). The sunbelt/snowbelt controversy: the war over federal funds. New York: New York University Press.

Erickson, R.S., \& Wright, G.C. (2001). Voters, candidates, and issues in congressional elections. In Dodd, L., \& Oppenheimer, B. (Eds.), congress reconsidered, $7^{\text {th }}$ ed., (pp. 67-95). Washington, DC: Congressional Quarterly Press.

Espenshade, T.J., \& Calhoun, C.A. (1993). An analysis of public opinion toward undocumented immigration. Population Research and Policy Review, 12(3), 189-224.

Fiellin, A. (1962). The function of informal groups: a state delegation. Journal of Politics 106, 72-91.

Fraga, L.R., Garcia, J.A., Hero, R., Jones, C.M., Martinez, E.V., \& Segura, G.M. Latino national survey (LNS), 2006 [Computer files.] ICPSR20862-v4. Ann Arbor, MI: Inter-University Consortium for Political and Social Research.

Hall, R. (1996). Participation in congress. New Haven, CT: Yale University Press.

Hammond, S. (1991). Congressional caucuses and party leaders in the house of representatives. Political Science Quarterly 106, 277-94.

Hammond, S. (1998). Congressional caucuses in national policy making. Baltimore, MD: Johns Hopkins University Press.

Hammond, S. (2001). Congressional caucuses in national policy making. Baltimore, MD: Johns Hopkins University Press

Hammond, S., Stevens, A., \& Mulholland, D. (1985). Informal congressional caucuses and agenda setting. Western Political Quarterly $38,583-606$.

Hammond, S., Mulholland, D., \& Stevens, A. (1983). Congressional caucuses: legislators as lobbyists. In Cigler, A., \& Loomis, B., (Eds.), Interest group politics. Washington, DC: Congressional Quarterly Press.

Hero, R., \& Tolbert, C. (1995). Latinos and substantive representation in the U.S. house of representatives: direct, indirect, or nonexistent? American Journal of Political Science, 39(3), 640-52.

Hutchings, V. (1998). Issue salience and support for civil rights legislation among southern democrats. Legislative Studies Quarterly, 239(40), 521-44.

Kingdon, J. (1989). Congressmen's voting decisions, $3^{\text {rd }}$ ed. Ann Arbor: the University of Michigan Press.

Knoll, B. (2009). Amigo de la raza? Reexamining determinants of latino support in the U.S. congress. Social Science Quarterly, 90(1), 179-95.

Loomis, B. (1981). Congressional caucuses and the politics of representation. In Dodd, L., \& Oppenheimer, B. (Eds.), Congress reconsidered, $2^{\text {nd }}$ ed., Washington, DC: Congressional Quarterly Inc.

Loomis, B. (1988). The new American politician. New York: basic books.

Loomis, B., \& Schiller, W. (2004). The contemporary Congress, $4^{\text {th }}$ ed. Belmont, CA: Wadsworth.

Mayhew, D. (1974). Congress: the electoral connection. New Haven, CT: Yale University Press.

Miller, C. (1990). Agenda-setting by state legislative black caucuses: policy priorities and factors of success. Policy Studies Review 9, 339-54.

Pinney, N., \& Serra, G. (1999). The congressional black caucus and vote cohesion: placing the caucus within house voting patterns. Political Research Quarterly, 52(3), 583-608.

Preston, M.B. (1978). Black elected officials and public policy: symbolic or substantive representation? Policy Studies Journal 7, 196-201.

Rohde, D. (1989). Something's happening here: what it is ain't exactly clear: southern democrats in the House of Representatives. In: Fiorina, M., \& Rohde, D. (Eds.), Home Style and Washington Work. Ann Arbor: University of Michigan Press. 
Rocca, M., Sanchez, G.R., \& Uscinski, J. (2008). Personal attributes and latino voting behavior in congress. Social Science Quarterly, 89(2), 392-405.

Rosso, A. Office of the Honorable Silvestre Reyes. Re: congressional border caucus. E-mail to the author. 3 March 2006.

Stevens, J.A.G., Miller, A.H., \& Mann, T. (1974). Mobilization of liberal strength in the House, 1955-1970: the democratic study group. American Political Science Review 68, 667-81.

Stevens, J.A.G., Mulhollan, D., \& Rundquist, P. (1981). U.S. Congressional structure and representation: the role of informal groups. Legislative Studies Quarterly 4, 415-37.
Swain, C. (1992). Changing patterns of African-American representation in congress. In Hertzke, A., \& Peters, J.R., (Eds.). The Atomistic Congress. Armonk, NY: M.E. Sharpe.

Swers, M. (1998). Are women more likely to vote for women's issue bills than their male colleagues?. Legislative Studies Quarterly, 23(3), 43548.

Vega, A. (1993). Confessions of a Congressman. Westport, CT: Greenwood.

Welch, S., \& Hibbing, J. (1984). Hispanic representation in the U.S. Congress. Social Science Quarterly, 65(2), 328-35.

(c) W.R. Mack; Licensee Bentham Open.

This is an open access article licensed under the terms of the Creative Commons Attribution Non-Commercial License (http://creativecommons.org/licenses/by-nc/3.0/) which permits unrestricted, non-commercial use, distribution and reproduction in any medium, provided the work is properly cited. 